ЕЛЕКТРОНІКА

РАДІОТЕХНІКА

ЗАСОБИ ТЕЛЕКОМУНІКАЦЙ

ELECTRONICS

RADIO ENGINEERING

TELECOMMUNICATION FACILITIES

O.A. Dobrozhan, master,

A.S. Opanasyuk, Dr. techn. sciences, prof.,

S.B. Bolshanina, Ph. D., ass. prof.,

Sumy state univ.

\title{
STRUCTURAL AND MICROSTRUCTURAL PROPERTIES OF ZnO THIN FILMS OBTAINED BY SPRAY PYROLYSIS TECHNIQUE
}

О.А. Доброжан, А.С. Опанасюк, С.Б. Больианіна. Структурні та мікроструктурні властивості тонких плівок ZnO, отриманих методом спрей-піролізу. Методами дифрактометрії та скануючої електронної мікроскопії досліджені плівки оксиду цинку, отримані методом спрей-піролізу при різних температурах підкладки зі скла. Як вихідний прекурсор використано дигідрат ацетату цинку, розчинений в дистильованій воді, що мав концентрацію 0,3 М. Досліджено вплив температури підкладки на розміри кристалів, фазовий склад, якість текстури, розміри областей когерентного розсіювання плівок, період кристалічної гратки матеріалу. Результати досліджень можуть бути використані при розробці функціональних шарів тонкоплівкових сонячних елементів.

Ключові слова: оксид цинку, тонкі плівки, спрей-піроліз, структурні та мікроструктурні властивості.

А.А. Доброжан, А.С. Опанасюк, С.Б. Большанина. Структурные и микроструктурные свойства тонких пленок ZnO, полученных методом спрей-пиролиза. Методами дифрактометрии и сканирующей электронной микроскопии исследованы пленки оксида цинка, полученные методом спрей-пиролиза при разных температурах подложки из стекла. В качестве исходного прекурсора использовался дигидрат ацетата цинка, растворенный в дистиллированной воде с концентрацией $0,3 \mathrm{M}$. Исследовано влияние температуры подложки на размеры кристаллов, фазовый состав, качество текстуры, размеры областей когерентного рассеивания пленок, период кристаллической решетки материала. Результаты исследований могут быть использованы при разработке функциональных слоев тонкопленочных солнечных элементов.

Ключевые слова: оксид цинка, тонкие пленки, спрей-пиролиз, структурные и микроструктурные свойства.

O.A. Dobrozhan, A.S. Opanasyuk, S.B. Bolshanina. Structural and microstructural properties of ZnO thin films obtained by spray pyrolysis technique. The $\mathrm{ZnO}$ thin films obtained by spray pyrolysis method applied at different temperatures of glass substrates have been studied by the methods of $X$-ray diffraction and scanning electron microscopy. The zinc acetate dihydrate dissolved in distilled water (concentration of $0,3 \mathrm{M}$ )

(C) O.A. Dobrozhan, A.S. Opanasyuk, S.B. Bolshanina, 2013

ЕЛЕКТРОНІКА. РАДІОТЕХНІКА. ЗАСОБИ ТЕЛЕКОМУНІКАЦІЙ 
was used as an initial precursor. The influence of substrate temperature on the grain size, phase structure, films' texture quality, lattice constants, size of coherent scattering domains has been studied. The research results can be used in the development of functional solar cells layers.

Keywords: zinc oxide, thin films, spray pyrolysis, structural and microstructural features.

\section{Introduction}

The zinc oxide $(\mathrm{ZnO})$ is a semiconductor of $n$-type conductivity with a high value of direct band gap $(3,37 \mathrm{eV}$ at $T=300 \mathrm{~K})$ and the highest exciton building energy $(60 \mathrm{meV})$ among binary compounds $[1,2]$. This material due to its unique physical, electrical and optical properties, chemical and thermal stability of the atmosphere and non-toxicity is very promising to be used in micro- and nanoelectronics [3, 4], optoelectronics [5, 6], sensorics [7...10], solar energy engineering [11...13] and others. As zinc oxide does not contain in its composition rare materials and can be obtained using low-cost methods, it is an alternative to traditional materials such as ITO $\left(\left(\operatorname{In}_{2} \mathrm{O}_{3}\right)_{0,9}-\left(\mathrm{SnO}_{2}\right)_{0,1}\right)$ and FTO $\left(\mathrm{SnO}_{2}: \mathrm{F}\right)[14]$. In addition, zinc oxide can be used in the construction of solar cells as antireflective coating, window material $[15,16]$.

For zinc oxide thin films synthesis a wide range of techniques that include magnetron sputtering $[17,18]$, chemical vapor deposition [19], thermal evaporation [20], chemical bath deposition [21, 22], spray pyrolysis [23...26] is used. In comparison with these methods, spray pyrolysis is simple, relatively inexpensive, non-vacuum deposition method for dense, porous thin film coatings and nanostructures of large area on different substrates. When using this method, the properties of thin films depend on the choice of precursors, physical and technological conditions of deposition of films. The analysis of the literature data [23...26] shows that substrate temperature has the greatest influence on the properties of the deposited thin films. Accordingly, the main goal of this work is to study the influence of substrate temperature on the structural and microstructural properties of $\mathrm{ZnO}$ thin films deposited by spray pyrolysis.

\section{Experimental details}

The laboratory setup, the schematic diagram of which is shown in Fig. 1, was used for obtaining zinc oxide thin films. $\mathrm{Zn}\left(\mathrm{CH}_{3} \mathrm{COO}\right)_{2} \cdot 2 \mathrm{H}_{2} \mathrm{O}$ dehydrate zinc acetate solution and distilled water with $\mathrm{Zn}(\mathrm{Ac})_{2}$ concentration of $0,3 \mathrm{M}$ were taken as a precursor. The laboratory setup consists of a heater, with the help of which the steel plate with fixed substrate is heated; a thermocouple for registering the values of the substrate temperature, a spray gun, comprising: a reservoir for the initial solution, nozzle atomization. The compressor, that provides air flow to transport dispersed precursor particles to the heated substrate, is connected to this gun.

A few drops of $\mathrm{HCl}$ were added to the initial solution to increase the degree of precursor solubility. Spraying of the initial solution was carried out on the glass substrate, cleaned before by ethanol, with the size of $2,5 \times 2,5 \mathrm{~mm}$. Substrate temperature range was $473 \ldots 673 \mathrm{~K}$ at intervals of increase of $50 \mathrm{~K}$. The distance between the nozzle and the heated substrate surface was equal to $20 \mathrm{~cm}$. To transport dispersed precursor particles the air flow with a pressure of $0,2 \mathrm{MPa}$ was used. Spraying rate was $2 \mathrm{ml} / \mathrm{min}$ at a volume of sprayed solution of $5 \mathrm{ml}$ per sample. It should be noted that spraying was performed in cycles (each spraying in $3 \mathrm{sec}$ ) to enable the film formation without saturation of precursor at the

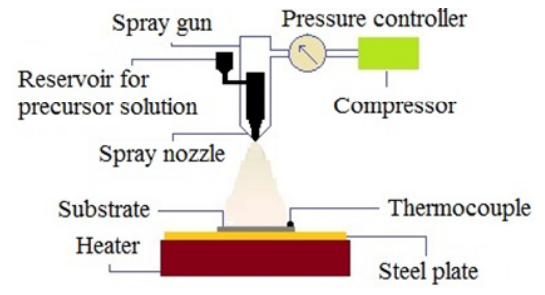

Fig. 1. Schematic diagram of experimental laboratory setup for obtaining $\mathrm{ZnO}$ thin films by spray-pyrolysis surface of the heated substrate.

During spray pyrolysis, dispersed precursor particles, while approaching within the close distance to the surface of the heated substrate, are subjected to thermal decomposition, as the result of which the evaporation of reaction products, followed by the formation of zinc oxide film, occurs.

X-ray analysis method using X-ray diffractometer DRON 4-07 in Ni-filtered K $\alpha$ radiation of copper anode $(U=30 \mathrm{kV}, I=20 \mathrm{~mA})$ was used to determine the structural properties. The measurement was conducted in a range of $2 \theta$ angles from $20^{\circ}$ to $80^{\circ}$, where $2 \theta$ is Bragg's angle. Curves were normalized to the peak intensity of the (101) hexagonal phase of the compound. Phase analysis was performed by comparing inter-plane distances and relative intensities of the researched samples and the standard according to JCPDS [27]. 
The texture of the films has been estimated by Harris method, which is convenient for research of flat samples with the axis of the texture that is oriented normally to the surface [28]. Pole density was calculated by the following formula:

where

$$
P_{i}=\frac{I_{i} / I_{0 i}}{\frac{1}{N} \sum_{i=1}^{N}\left(I_{i} / I_{0 i}\right)},
$$

$I_{i}, I_{0 i}$ - integrated intensities of the $i$-th diffraction peak for the film sample and standard;

$N$ - the number of lines that are present on the diffraction pattern.

Then $P_{i}-(h k l)_{I}$ and $P_{i}-\varphi$ dependences, where $\varphi$ is the angle between the axis of the texture and perpendicular to different crystallographic planes, which correspond to reflections on the diffractograms, $(h k l)$ - Miller indexes were made. This angle was calculated for the hexagonal lattice, using the expressions given in [28]. Texture axis has those indexes, which correspond to the largest value of $P_{i}$. In this case, the orientation factor for the sample can be calculated from the expression

$$
f=\sqrt{\frac{1}{N} \sum_{i=1}^{N}\left(P_{i}-1\right)^{2}} .
$$

Calculation of the constants $a$ and $c$ of the hexagonal phase of the material was held by the formulas:

$$
\begin{aligned}
& a=\frac{\lambda}{2 \sin \theta} \sqrt{\frac{4}{3}\left(h^{2}+h k+k^{2}\right)+\left(\frac{a}{c}\right)^{2} l^{2}}, \\
& a=\frac{\lambda}{2 \sin \theta} \sqrt{\frac{4}{3}\left(\frac{c}{a}\right)^{2}\left(h^{2}+h k+k^{2}\right)+l^{2}} .
\end{aligned}
$$

The lattice constants were determined using Nelson-Riley extrapolation method [29, 30]. The graphs in the coordinates $a(c)-\frac{1}{2} \cos ^{2} \theta\left(\frac{1}{\sin \theta}+\frac{1}{\theta}\right)$ were plotted. Thus a graphical method of successive approximations was used to determine the lattice constants of hexagonal phase. The linear approximation of obtained points was conducted using the method of least squares with the help of OriginPro software package. This method, performed at the intersection of the line with the axis of ordinates, allows finding the lattice constants with an accuracy of $0,001 \%$.

The average size of coherent scattering domains (CSD) $L$ was determined by Scherer's formula [31]:

where

$$
L=\frac{k \cdot \lambda}{\beta \cdot \cos \theta},
$$

$k$ - coefficient that depends on the shape of the particle $(k=1)$;

$\lambda$ - wavelength of X-rays;

$\beta$ - broadening of the corresponding X-ray lines;

$\theta$ - diffraction angles of the analyzed lines.

More detailed methodology for determining the structural and microstructural characteristics of the films are described in $[29,30 \ldots 32]$.

\section{Results and discussions}

Fig. 2 shows the electron microscopy images of the surface of zinc oxide films deposited at different substrate temperatures.

It should be noted that at temperatures of $523 \mathrm{~K}$ the formation of the polycrystalline film with crystal growth at different angles to the plane of the substrate occurred. By increasing the substrate temperature to $673 \mathrm{~K}$ the formation of grains with a hexagonal prism shape with diameters of $0,8 \ldots 1 \mu \mathrm{m}$ happened.

Fig. 3 shows the diffraction patterns of $\mathrm{ZnO}$ films deposited at different substrate temperatures. Phase analysis of samples was carried out using handbook (JCPDS cards № 36-1451 and 21-1467) 
[27]. In the diffractograms the line was dominant in the angles of $36,16^{\circ} \ldots 36,32^{\circ}$, which corresponded to the reflection from the plane (101) of the hexagonal phase of $\mathrm{ZnO}$. Also the lines with a sufficiently large intensity at angles of $31,82^{\circ}, 34,44^{\circ}, 47,5^{\circ}, 56,7^{\circ}, 62,88^{\circ}, 67,92^{\circ}, 69,04^{\circ}$, where the intensive reflections from planes (100), (002) (102) (110) (103 ) (112) (201) at wurtzite phase of ZnO were present on diffractograms. Thus diffraction analysis shows that the samples have a hexagonal structure.
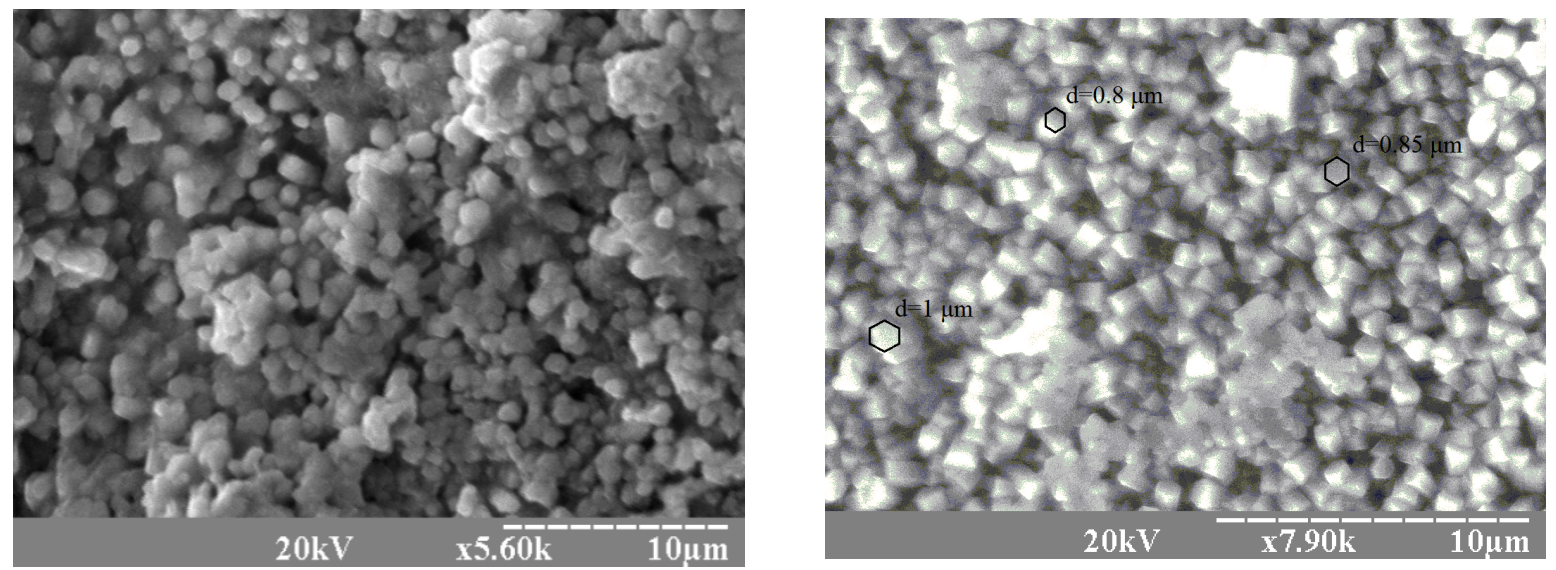

Fig. 2. SEM images of the surface of the ZnO films obtained at non-oriented substrates at substrate temperatures of $T_{s}: 523 \mathrm{~K}(\mathrm{a})$ and $673 \mathrm{~K}(\mathrm{~b})$

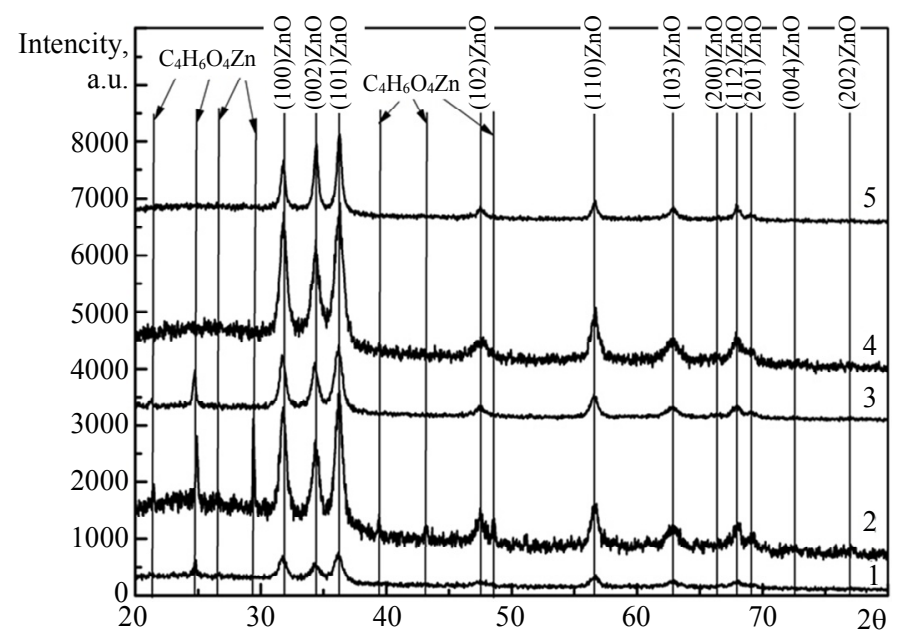

Fig. 3. XRD patterns of ZnO films obtained at different substrate temperatures, $T_{s}, K$ : 473(1), 523 (2), 573 (3), 623 (4), 673 (5)

To be noted is that $\mathrm{C}_{4} \mathrm{H}_{6} \mathrm{O}_{4} \mathrm{Zn}$ phases, which were identified by means of a JCPDS 21-1467 card, are present at substrate temperatures of $473 \mathrm{~K}, 523 \mathrm{~K}, 573 \mathrm{~K}$ [27]. The analysis diffraction has shown that peaks from zinc acetate phase decreases with increasing substrate temperature. Films obtained at temperatures above $573 \mathrm{~K}$ were single phase and contained only hexagonal phase of $\mathrm{ZnO}$.

Calculations of pole density $P_{i}$ made it possible to determine the axial texture of growth in $\mathrm{ZnO}$ layers [002], the perfection of which was identified by modes of the obtained films and which increased with increased thickness (Fig. 4,a).

Appropriate dependences of film's orientation factor on the substrate temperature at which they were obtained are presented in Fig. 4, $b$. As can be seen from the figure, with increasing the substrate temperature, the corresponding value of orientation factor also increases. This suggests that with increasing the substrate temperature the quality of obtained films' textures increases. 

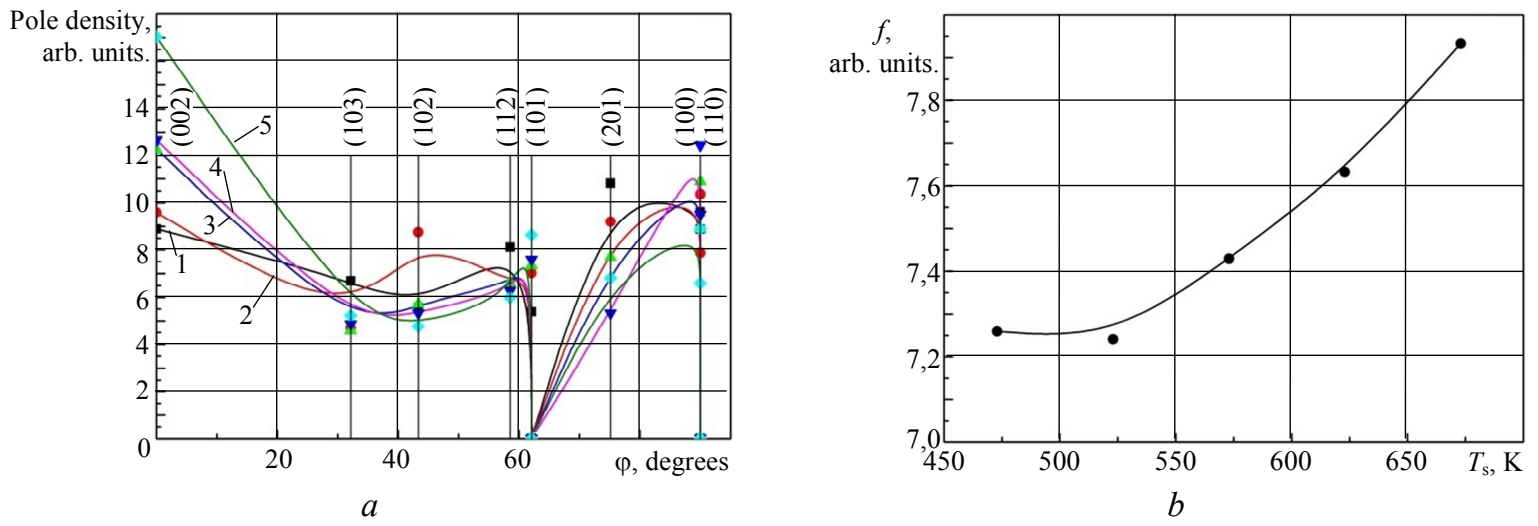

Fig. 4. Pole density $\left(P_{i}\right)$ as a dependent function of the angle $\varphi$ between the axis of the texture and normal to the reflecting plane at temperatures $(a)$ and orientation factor $(f)$ for films obtained at different substrate temperatures $T_{s}, K: 473(1), 523$ (2), 573 (3), 623 (4), 673 (5)

The results of calculating the size of coherent scattering domains in $\mathrm{ZnO}$ films in directions perpendicular to crystallographic planes (100), (110) and (002) are shown in Fig. 5. It is established that with the change of the substrate temperature the sizes of CSD take the following values: $\quad L_{(100)}=14 \ldots 20, \quad L_{(110)}=12 \ldots 25$, $L_{(002)}=16 \ldots 23 \mathrm{~nm}$. In general, one can trace the growth of the CSD sizes in their corresponding areas with increasing the substrate temperature that shows the growth of the crystalline quality of the films.

The lattice constant of material is a characteristic which is extremely sensitive to changes of its stehiometry, adding impurities, oxidation and others, that's why precision calculation of these parameters makes it possible to study the relevant processes. We carried X-ray determination of lattice constants of $\mathrm{ZnO}$ films, deposited at different modes of condensation.

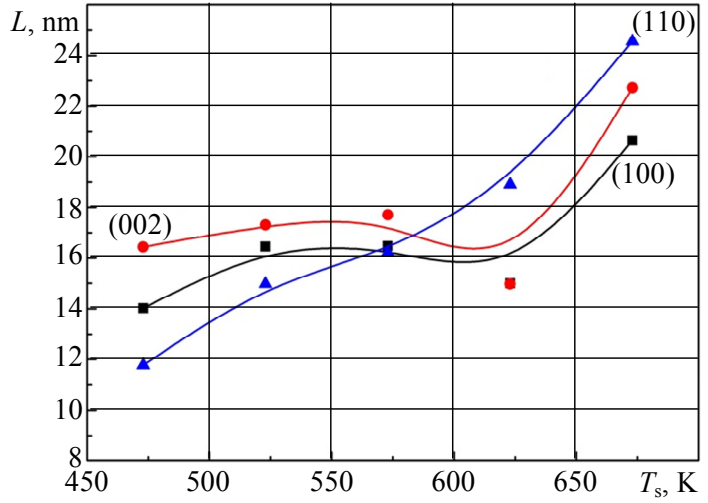

Fig. 5. Dependence of CSD sizes in ZnO films on the substrate temperature. Values for crystal planes (100), (110) and (002) are presented The obtained values of crystal lattice of the material after the 5th iteration are shown in Table.

The results of calculations of the lattice constants of $\mathrm{ZnO}$ films obtained using the Nelson-Riley

\begin{tabular}{c|c|c|c}
\hline \multirow{2}{*}{$T_{s}, \mathrm{~K}$} & \multicolumn{3}{|c}{ 5-th iteration } \\
\cline { 2 - 4 } & $a$ & $c$ & $c / a$ \\
\hline 473 & 0,32481 & 0,51495 & 1,5854 \\
\hline 523 & 0,32513 & 0,51743 & 1,5916 \\
\hline 573 & 0,32414 & 0,52382 & 1,6160 \\
\hline 623 & 0,32601 & 0,51509 & 1,5994 \\
\hline 673 & 0,32544 & 0,52036 & \\
\hline Reference value & \multicolumn{3}{|c}{$a=0,3249, c=0,5206, c / a=1,6023[27]$} \\
\hline
\end{tabular}

The calculated values of lattice constants $(a=0,3241 \ldots 0,3260 \mathrm{~nm}$ and $c=0,51495 \ldots 0,52382 \mathrm{~nm}, c / a=1,5800 \ldots 1,6160)$ correlate with the data given in the JCPDS $(a=0,3249 \mathrm{~nm}, c=0,5206 \mathrm{~nm}, c / a=1,6023)[27]$.

\section{Conclusions}

In this paper, $\mathrm{ZnO}$ films obtained by the $\mathrm{X}$-ray diffraction method and scanning electron microscopy with the help of the spray pyrolysis method using the solution of $\mathrm{Zn}\left(\mathrm{CH}_{3} \mathrm{COO}\right)_{2} \cdot 2 \mathrm{H}_{2} \mathrm{O}$ with the 
concentration of $0,3 \mathrm{M}$ as a precursor have been investigated. The influence of substrate temperature on the crystal size, phase composition, texture quality, size of coherent scattering domains films, lattice constants of the material is investigated.

It is shown that the films have polycrystalline structure with a grain size of $0,1 \ldots 1 \mu \mathrm{m}$, which increases with increasing substrate temperature. It was shown by means of X-ray diffraction that the films obtained at temperatures below $573 \mathrm{~K}$ are two-phase and contain zinc acetate along with hexagonal phase $\mathrm{ZnO}$. Films obtained at higher temperatures were single phase and had the texture of axial growth [002].

Established is that with the change of the substrate temperature the CSD sizes acquire growing nature and take the following values in the respective planes: $L_{(100)}=14 \ldots 20, L_{(110)}=12 \ldots 25$, $L_{(002)}=16 \ldots 23 \mathrm{~nm}$. The calculated values of lattice constant $a=0,3241 \ldots 0,3260 \mathrm{~nm}$, $c=0,51495 \ldots 0,52382 \mathrm{~nm}, c / a=1,5800 \ldots 1,6160)$ mostly correlate to reference ones.

Thus, the modes to obtain single-phase zinc oxide films with rather big CSD sizes that states about their high crystalline quality were defined. These obtained layers can be used as windows of thin-film solar cells.

\section{Acknowledgments}

This work is supported by the Ukraine State Agency for the Science, Innovation and Informatization and by the Ministry of Education and Science of Ukraine (Grant No. 0113U000131, 0112U000772).

\section{Literature}

1. Özgür, Ü. A Comprehensive Review of ZnO Materials and Devices / Ü. Özgür, Ya.I. Alivov, A. Teke, M.A. Reshchikov, S. Doğan, V. Avrutin, S.-J. Cho, H. Morkoç // Applied Physics Reviews. — 2005. Vol. 98. - PP. 041301-1 - 041301-102.

2. Kireev, V.V. Growth of Thin ZnO Films by Ultrasonic Spray Pyrolysis / V.V. Kireev, L.N. Dem'yanets, L.E. Li, V.V. Artemov // Inorganic Materials. — 2010. — Vol. 46, \# 2. — PP. 154 - 162.

3. Semikina, T.V. Oksidnaya electronica kak odno iz napravlenii prozrachnoi electroniki [Oxide electronics as one as direction of the transparent electronics] / T.V. Semikina, L.N. Shmyreva // Electronika i svyaz. Tematicheskii vypusk "Electronika i nanotekhnologii" [Electronics and Connection. Thematic release "Electronics and Nanotechnology"]. - 2010. - Vol. 3. - PP. $20-28$.

4. Wang, Z.L. Ten Years' Venturing in ZnO Nanostructures: from Discovery to Scientific Understanding and to Technology Applications / Z.L. Wang // Chinese Science Bulletin. - 2009. - Vol. 54. PP. $4021-4034$.

5. Djurišić, A.B. ZnO Nanostructures for Optoelectronics: Material Properties and Device Applications / A.B. Djurišić, A.M.C. Ng, X.Y. Chen // Progress in Quantum Electronics. - 2010. - Vol. 34. PP. $191-259$.

6. Look, D.C. Recent Advances in $\mathrm{ZnO}$ Materials and Devices / D.C. Look // Material Science and Engineering B. - 2001. - Vol. 80. - PP. 383 - 387.

7. Shewale, P.S. Thickness Dependent H2S Sensing Properties of Nanocrystalline ZnO Thin Films Derived by Advanced Spray Pyrolysis / P.S. Shewale, G.L. Agawane, S.W. Shin, A.V. Moholkar, J.Y. Lee, J.H. Kim, M.D. Uplane // Sensors and Actuators B. — 2013. — Vol. 177. — PP. 695 - 702.

8. Prajapati, C.S. Studies on Metal-Oxide Semiconductor $\mathrm{ZnO}$ as a Hydrogen GAS Sensor / C.S. Prajapati, P.P. Sahay // Journal of Nano- and Electron Physics. — 2011. - Vol. 3, \# 1. — PP. 714 - 720.

9. Mariappan, R. Influence of Molar Concentration on the Physical Properties of Nebulizer-Sprayed ZnO Thin Films for Ammonia Gas Sensor / R. Mariappan, V. Ponnuswamy, M. Ragavendar // Materials Science in Semiconductor Processing. - 2013. - Vol. 16. - PP. $1328-1335$.

10. Wei, A. Recent Progress in the ZnO Nanostructure-Based Sensors / A. Wei, L. Pan, W. Huang // Materials Science and Engineering B. - 2011. - Vol. 176. - PP. 1409 - 1421.

11. Gledhill, S. A Spray Pyrolysis Route to the Undoped $\mathrm{ZnO}$ Layer of $\mathrm{Cu}(\mathrm{In}, \mathrm{Ga})(\mathrm{S}, \mathrm{Se}) 2$ Solar Cells / S. Glehill, A. Grimm, N. Allsop, T. Koehler, C. Camus, M. Lux-Steiner, C.-H. Fischer // Thin Solid Films. - 2009. - Vol. 517. - PP. $2309-2311$.

12. Crossay, A. Spray-Deposited Al-Doped ZnO Transparent Contacts for CdTe Solar Cells / A. Crossay, S. Buecheler, L. Kranz, J. Perrenoud, C.M. Fella, Y.E. Romanyuk, A.N. Tiwari // Solar Energy Materials \& Solar Cells. - 2012. - Vol. 101. - PP. 283 - 288.

13. Kärber, E. Electrical Characterization of All-Layers-Sprayed Solar Cell Based on ZnO Nanorods and Extremely Thin CIS Absorber / E. Kärber, A. Abass, S. Khelifi, M. Burgelman, A. Katerski, M. Krunks // Solar Energy. — 2013. — Vol. 91. — PP. 48 - 58. 
14. Mahajan, C.M. Intermittent Spray Pyrolytic Growth of Nanocrystalline and Highly Oriented Transparent Conducting ZnO Thin Films: Effect of Solution Spray Rate / C.M. Mahajan, M.G. Takwale // Journal of Alloys and Compounds. - 2014. - Vol. 584. - PP. 128 - 135.

15. Levy-Clement, C. CdSe-Sensitized $p$-CuSCN/Nanowire n-ZnO Heterojunctions / C. Levy-Clement, R. TenaZaera, M.A. Ryan, A. Katty, G. Hodes // Advenced Materials. — 2005. — Vol. 12. — PP. 1512 - 1515.

16. Krunks, M. Nanostructured Solar Cell Based on Spray Pyrolysis Deposited ZnO Nanorod Array / M. Krunks, A. Katerski, T. Dedova, I. Oja Acik, A. Mere // Solar Energy Materials and Solar Cells. 2008. - Vol. 9. - PP. 1016 - 1019.

17. Liu, Z.W. Morphology and Interface Characteristics of ZnO Films Deposited at Room Temperature and $750{ }^{\circ}$ C / Z.W. Liu, C.W. Sun, Q.Y. Zhang, Y.N. Wang, B. Wu, Z.X. Jin // Surface and Coatings Technology. - 2007. - Vol. 201. — PP. 5422 - 5426.

18. Gao, W. ZnO Thin Films Produced by Magnetron Sputtering / W. Gao, L. Zhengwei // Ceramics International. - 2004. - Vol. 30, \# 7. - PP. 1155 - 1159.

19. Fay, S. Low Pressure Chemical Vapour Deposition of ZnO Layers for Thin-Film Solar Cells: Temperature-Induced Morphological changes / S. Fay, U. Kroll, C. Bucher, E. Vallat-Sauvain, A. Shah // Solar Energy Materials and Solar Cells. - 2005. - Vol. 86, \# 3. - PP. 385 - 397.

20. Aly, S.A. Effect of Annealing on the Optical Properties of Thermally Evaporated ZnO Films / S.A. Aly, N.Z. El Sayed, M.A. Kaid // Vacuum. - 2001. — Vol. 61, \# 1. - PP. 1 - 7.

21. Gurav, K.V. Room Temperature Soft Chemical Route for Nanofibrous Wurtzite ZnO Thin Film Synthesis / K.V. Gurav, V.J. Fulari, U.M. Patil, C.D. Lokhande, O.S. Joo // Applied Surface Science. 2010. - Vol. 256. - PP. $2680-2685$.

22. Opanasyuk, A.S. Structural and Sub-Structural Seatures of Chemically Deposited Zinc-Oxide Thin Films / A.S. Opanasyuk, T.O. Berestok, P.M. Fochuk, A.E. Bolotnikov, R.B. James // Processing of SPIE. - 2013. - Vol. 8823. - PP. 88230Q-1 - 88230Q-6.

23. Ashour, A. Physical Properties of $\mathrm{ZnO}$ Thin Films Deposited by Spray Pyrolysis Technique / A. Ashour, M.A. Kaid, N.Z. El-Sayed, A.A. Ibrahim // Applied Surface Science. - 2006. — Vol. 252. PP. $7844-7848$.

24. Ayouchi, R. Preparation and Characterization of Transparent ZnO Thin Films Obtained by Spray Pyrolysis / R. Ayouchi, D. Leinen, F. Martin, M. Gabas, E. Dalchiele, J.R. Ramos-Barrado // Thin Solid Films. - 2003. - Vol. 426. - PP. 68 - 77.

25. Jayakrishnan, R. ZnO Thin Films with Blue Emission Grown Using Chemical Spray Pyrolysis / R. Jayakrishnan, K. Mohanachandran, S. Sreekumar, S. Sudha Kartha, K.P. Vijayakumar // Materials Science in Semiconductor Processing. - 2013. - Vol. 16. - PP. 326 - 331.

26. Tarwal, N.L. Growth of Multifunctional ZnO Thin Films by Spray Pyrolysis Techniqu / N.L. Tarwal, A.V. Rajgure, A.I. Inamdar, R.S. Devan, I.Y. Kim, S.S. Suryavanshi, Y.R. Ma, J.H. Kim, P.S. Patil // Sensors and Actuators A. - 2013. - Vol. 199. — PP. 67 - 73.

27. Selected Powder Diffraction Data for Education Straining / Search Manual and Data Cards // Published by the International Center for Diffraction Data. - 1997. — USA. - P. 432.

28. Umanskij, Ja.S. Crystallogaphy, X-ray graph and electronmicroscopy / Ja.S. Umanskij, Ju.A. Skakov, A.N. Ivanov, L.N. Rastorgujev // Moskov: Metallurgiya. — 1982. — P. 632.

29. Opanasyuk, A.S. Characteristics of Structure Formation in Zinc and Cadmium Chalcogenide Films Deposited on Nonorienting Substrates / A.S. Opanasyuk, D.I. Kurbatov, V.V. Kosyak, S.I. Kshniakina, S.N. Danilchenko // Crystallography Reports. - 2012. — Vol. 57. — PP. 927 - 933.

30. Berestok, T.O. Structural Properties of ZnO Thin Films Obtained by Chemical Bath Deposition Technique / T.O. Berestok, D.I. Kurbatov, N.M. Opanasyuk, A.D. Pogrebnjak, A.D. Manzhos, S.M. Danilchenko // Journal of Nano- and Electron Physics. — 2013. Vol. 5, \# 1. - PP. $01001-01004$.

31. Warren, B.E. X-ray Diffraction / B.E. Warren. New York: Dover. - 1990. — P. 253.

32. Kosyak, V.V. Structural and Electrical Properties of ZnS/CdTe and ZnTe/CdTe Heterostructures / V.V. Kosyak, D.I. Kurbatov, M.M. Kolesnyk, A.S. Opanasyuk, S.N. Danilchenko, Yu. P. Gnatenko // Journal of Materials Chemistry and Physics. — 2013. - Vol. 138. — PP. 731 - 736. 